\title{
ANALISA SIX SIGMA PADA PROSES PEMBENGKOKAN (BENDING) MAIN WATER TUBE
}

\author{
Adhiela Noer Syaief \\ Jurusan Mesin Otomotif Politeknik Negeri Tanah Laut
}

\begin{abstract}
ABSTRAK
Kemampuan menggunakan alat ukur untuk mengetahui gambaran proses produksi merupakan keunggulan bagi perusahaan-perusahaan. Apalagi dengan persaingan yang ketat menuntut perusahaan - perusahaan untuk bisa menentukan bahkan meningkatkan kualitas hasil produksinya. Salah satu alat ukur yang digunakan untuk mengetahui kualitas hasil produksi adalah dengan melakukan analisa SIX SIGMA. Analisa ini dilakukan di PT. INDOMARINE, analisa diawali dengan menetapkan karakteristik kualitas (CTQ), pengukuran variabel (DPMO dan Sigma Level) dan tahapan terakhir adalah perhitungan kemampuan proses (Process Capability).Berdasarkan perhitungan, maka didapatkan nilai DPMO sebesar 37’494 dan sigma level sebesar 3,28 sehingga kemampuan proses dalam ukuran nilai sigma adalah sebesar 3,28 sigma.
\end{abstract}

Kata Kunci: Six Sigma, DPMO, Sigma Level, Kemampuan Proses, CTQ

\section{PENDAHULUAN}

PT. INDOMARINE Factory Div. Boiler merupakan salah satu perusahaan yang memproduksi Boiler (ketel uap) dan komponen - komponen boiler. Untuk menghadapi persaingan dengan perusahaan - perusahaan yang sejenis maka perusahaan ini ingin mengetahui kualitas hasil produksinya dengan melihat sigma level dan kemampuan proses. Dalam hal ini sigma level digunakan sebagai acuan dalam menentukan kondisi perusahaan, sehingga dapat diketahui pada posisi manakah perusahaan tersebut berada dan langkah apa yang akan diambil dalam mengurangi jumlah produk cacat yang ada.

PT. INDOMARINE memiliki produk - produk yang merupakan kompenen - komponen dari produk boiler. Salah satu produknya yaitu MAIN WATER TUBE. Dimana pada saat proses pembuatannya harus melalui standard kualitas yang ketat khususnya pada proses pembengkokan (bending). Dengan menggunakan analisa SIX SIGMA diharapkan perusahaan dapat mengetahui kualitas hasil produksinya (sigma level dan kemampuan proses) sebagai acuan perusahaan untuk menyusun program peningkatan kualitas.

Tujuan yang ingin dicapai dalam analisa ini adalah sebagai berikut :

1. Penerapan Analisa Six Sigma

2. Menghitung DPMO dan Sigma Level

3. Menentukan kemampuan proses.

\section{METODOLOGI}

Tahapan - tahapan yang digunakan dalam analisa ini adalah sebagai berikut

1. Define

Menentukan Critical to Quality (CTQ)
2. Measure

Di dalam tahap ini dilakukan pengukuran variabel, perhitungan DPMO, Sigma Level dan Kemampuan Proses.

a) Pengukuran Variabel

Pengukuran variabel adalah pengukuran yang dilakukan pada sejumlah sampel untuk mengetahui dan melakukan pendataan terhadap hasil proses sesuai spesifikasi yang ditetapkan.

b)Menghitung nilai DPMO

c) Sigma Level

Berdasarkan nilai DPMO yang sudah diperoleh, maka dapat dihitung sigma level untuk masing - masing proses.

d) Kemampuan Proses

Ditentukan berdasarkan sigma level.

\section{HASIL DAN PEMBAHASAN}

1. Define ( Mendefinisikan )

Masalah utama yang akan dianalisa adalah pada proses pembengkokan pipa pada produk MAIN WATER TUBE, dimana masih ada hasil proses yang berada di luar batas spesifikasi.

PENENTUAN Critical To Quality

Karaketeristik kualitas yang diinginkan adalah diameter pipa setelah proses bending dengan batas spesifikasi yaitu 76,200 $\pm 0,125 \mathrm{~mm}$.

2. Measure (Mengukur)

Pengukuran Variabel

Data pengukuran diameter (dalam milimeter) telah dilakukan terhadap 25 pipa selama 25 periode produksi. 
Tabel 1 Data Hasil Pengukuran Diameter Pipa

\begin{tabular}{|c|c|c|c|}
\hline Contoh & $\begin{array}{l}\text { Pengukuran } \\
\text { Diameter pipa } \\
(\mathrm{mm})\end{array}$ & $\begin{array}{c}\text { Range } \\
\text { bergerak } \\
\text { MR } \\
\end{array}$ & $\begin{array}{c}\text { Standar Deviasi } \\
\mathrm{S}=\mathrm{MR} / \mathrm{d}_{2}\end{array}$ \\
\hline 1 & 76.230 & & \\
\hline 2 & 76.210 & 0.020 & 0.017730 \\
\hline 3 & 76.075 & 0.135 & 0.119681 \\
\hline 4 & 76.150 & 0.075 & 0.066489 \\
\hline 5 & 76.221 & 0.071 & 0.062943 \\
\hline 6 & 76.271 & 0.050 & 0.044326 \\
\hline 7 & 76.206 & 0.065 & 0.057624 \\
\hline 8 & 76.210 & 0.004 & 0.003546 \\
\hline 9 & 76.157 & 0.053 & 0.046986 \\
\hline 10 & 76.275 & 0.118 & 0.104610 \\
\hline 11 & 76.290 & 0.015 & 0.013298 \\
\hline 12 & 76.291 & 0.001 & 0.000887 \\
\hline 13 & 76.298 & 0.007 & 0.006206 \\
\hline 14 & 76.210 & 0.088 & 0.078014 \\
\hline 15 & 76.215 & 0.005 & 0.004433 \\
\hline 16 & 76.073 & 0.142 & 0.125887 \\
\hline 17 & 76.141 & 0.068 & 0.060284 \\
\hline 18 & 76.075 & 0.066 & 0.058511 \\
\hline 19 & 76.131 & 0.056 & 0.049645 \\
\hline 20 & 76.077 & 0.054 & 0.047872 \\
\hline 21 & 76.275 & 0.198 & 0.175532 \\
\hline 22 & 76.195 & 0.080 & 0.070922 \\
\hline 23 & 76.158 & 0.037 & 0.032801 \\
\hline 24 & 76.097 & 0.061 & 0.054078 \\
\hline 25 & 76.226 & 0.129 & 0.114362 \\
\hline Jumlah & 1904.76 & 1.598 & - \\
\hline $\begin{array}{c}\text { Rata - } \\
\text { rata }\end{array}$ & 76.190 & 0.067 & 0.059028 \\
\hline \multicolumn{4}{|c|}{$\begin{array}{l}\text { Catatan }: M R=\text { adalah absolut selisih pengukuran } \\
\text { sesudah dan pengukuran sebelum. Sebagai misal }: \text { MR } \\
\text { untuk cintoh ke-2 adalah }: \text { Absolut }\left(X_{2}-X_{1}\right)=\text { Absolut } \\
(76.230-76.210) \text {. nilai } M R \text { selalu positif. } \\
\text { Perhitungan untuk proses secara keseluruhan (overall } \\
\text { process): } \\
\text { Rata }- \text { rata (mean) proses }=76.190 \mathrm{~mm} \\
\text { Standar deviasi proses }=\mathrm{S}=\mathrm{MR}-\mathrm{bar} / \mathrm{d}_{2}=0.067 / 1.128= \\
0.059028 \mathrm{~mm} \\
\text { Nilai } \mathrm{d}_{2} \text { yang dipergunakan adalah untuk ukuran contoh n } \\
=2 \text { yaitu }: 1.128\end{array}$} \\
\hline
\end{tabular}

\section{Perhitungan Nilai DPMO dan Sigma Level.}

Di dalam pengumpulan data guna menentukan nilai DPMO dan Sigma Level, data yang digunakan adalah diameter pipa pada produk MAIN WATER TUBE. Hasil perhitungan DPMO adalah = 37'494 dengan Sigma Level $=3,28$

\section{Perhitungan Kemampuan Proses}

Adapun perhitungan kemampuan proses untuk data diameter pipa pada produk MAIN WATER TUBE dapat dilihat pada tabel berikut

Tabel 2 Cara Penentuan Kapabilitas Proses, Nilai sigma dan DPMO untuk Data Variabel (CTQ = diameter pipa, dalam satuan pengukuran $\mathrm{mm}$ )

\begin{tabular}{|c|c|c|c|}
\hline Langkah & Tindakan & Persamaan & $\begin{array}{c}\text { Hasil } \\
\text { Perhitungan }\end{array}$ \\
\hline 1 & $\begin{array}{l}\text { Proses apa yang } \\
\text { ingin anda } \\
\text { ketahui? }\end{array}$ & - & $\begin{array}{l}\text { Bending } \\
\text { Pipa }\end{array}$ \\
\hline 2 & $\begin{array}{l}\text { Tentukan Nilai } \\
\text { batas spesifikasi } \\
\text { atas (upper } \\
\text { specification limit) }\end{array}$ & USL & 76.325 \\
\hline 3 & $\begin{array}{l}\text { Tentukan Nilai } \\
\text { batas spesifikasi } \\
\text { bawah (lower } \\
\text { specification limit) }\end{array}$ & LSL & 76.075 \\
\hline 4 & $\begin{array}{l}\text { Tentukan nilai } \\
\text { spesifikasi target }\end{array}$ & $\mathrm{T}$ & 76.200 \\
\hline 5 & $\begin{array}{l}\text { Berapa nilai rata - } \\
\text { rata (mean) proses }\end{array}$ & X-bar & 76.190 \\
\hline 6 & $\begin{array}{l}\text { Berapa nilai } \\
\text { standard deviasi } \\
\text { dari proses }\end{array}$ & $\mathrm{S}$ & 0.059028 \\
\hline 7 & $\begin{array}{l}\text { Hitung } \\
\text { kemungkinan } \\
\text { cacat yang berada } \\
\text { diatas nilai USL } \\
\text { per satu juta } \\
\text { kesempatan } \\
\text { (DPMO) }\end{array}$ & $\begin{array}{c}\mathrm{P}[\mathrm{z} \geq(\mathrm{USL} \\
-\mathrm{X}-\mathrm{bar}) / \mathrm{S}] \\
\mathrm{x} \\
\left.1000000^{*}\right)\end{array}$ & 11'304 \\
\hline 8 & $\begin{array}{l}\text { Hitung } \\
\text { kemungkinan } \\
\text { cacat yang berada } \\
\text { dibawah nilai LSL } \\
\text { per satu juta } \\
\text { kesempatan } \\
\text { (DPMO) }\end{array}$ & $\begin{array}{c}\mathrm{P}[\mathrm{z} \leq(\mathrm{LSL} \\
-\mathrm{X}-\mathrm{bar}) / \mathrm{S}] \\
\mathrm{x} \\
1000000 * *)\end{array}$ & $26 ’ 190$ \\
\hline 9 & $\begin{array}{l}\text { Hitung } \\
\text { kemungkinan } \\
\text { cacat per satu juta } \\
\text { kesempatan } \\
\text { (DPMO) yang } \\
\text { dihasilkan oleh } \\
\text { proses diatas } \\
\end{array}$ & $\begin{array}{l}=\text { langkah } 7 \\
+ \text { langkah } 8\end{array}$ & $37^{\prime} 494$ \\
\hline 10 & $\begin{array}{l}\text { Konversi DPMO } \\
\text { (langkah 9) ke } \\
\text { dalam nilai sigma } \\
\text { (lihat tabel } \\
\text { lampiran 5) }\end{array}$ & & $3.28 * * *)$ \\
\hline 11 & $\begin{array}{l}\text { Hitung } \\
\text { kemampuan } \\
\text { proses di atas } \\
\text { dalam ukuran nilai } \\
\text { sigma }\end{array}$ & - & $\begin{array}{c}\text { Kapabilitas } \\
\text { proses } \\
\text { adalah } 3.28- \\
\text { sigma }\end{array}$ \\
\hline
\end{tabular}

Catatan : *) P[z $\geq($ USL - X-bar $) / \mathrm{S}]$ x $1000000=\mathrm{P}[\mathrm{z} \geq(76.325-$ $76.190) / 0.059028] \times 1.000 .000=$

$\mathrm{P}(\mathrm{z} \geq 2.28) \times 1.000 .000=[1-\mathrm{P}(\mathrm{z} \leq 2.28)] \times 1.000 .000=(1-$ $0.988696) \times 1.000 .000=0.011304 \times 1.000 .000=11 ’ 304$

**) $\mathrm{P}[\mathrm{z} \leq(\mathrm{LSL}-\mathrm{X}$-bar $) / \mathrm{S}] \times 1000000=\mathrm{P}[\mathrm{z} \leq(76.075-$ $76.190) / 0.059028] \times 1.000 .000=$

$\mathrm{P}(\mathrm{z} \leq-1.94) \times 1.000 .000=0.026190 \times 1.000 .000=26^{\prime} 190$

***) Dari tabel lampiran 5 angka DPMO = 37’494 adalah paling 


\section{KESIMPULAN}

Berdasarkan penerapan dan analisa Six Sigma maka dapat diambil kesimpulan bahwa proses industri bending pipa di PT.INDOMARINE memiliki kapabilitas proses yang rendah, tampak bahwa DPMO masih tinggi yaitu : 37’494 DPMO yang dapat diinterpretasikan bahwa dari sejuta kesempatan yang ada akan terdapat 37'494 kemungkinan bahwa proses bending pipa itu tidak mampu memenuhi spesifikasi diameter 76,200 $\pm 0,125 \mathrm{~mm}$.

\section{DAFTAR PUSTAKA}

[1] Gaspersz, Vincent. 2002, Pedoman Implementasi Six Sigma : Terintegrasi dengan ISO 9001, MBNQA, dan HACCP, PT. Gramedia Pustaka Utama, Jakarta.

[2] Hutabarat, Julianus., Nursanti, Ellysa. 2007, Meningkatkan Kualitas Produk Melalui Konsep DMAIC Pada SIX SIGMA, Program Studi Teknik Industri, Malang.

[3] Kaban, Naksir. 2002, Pengendalian Kualitas Statistis, ITN, Malang. 